\title{
Efficient Electrogenerated Chemiluminescence from Cyclometalated Iridium(III) Complexes
}

Jae Il Kim, Ik-Soo Shin, Hasuck Kim, and Jin-Kyu Lee

\section{Experimental Section}

NMR spectra were recorded on Bruker DPX 300, Avance $500 \mathrm{MHz}$ instruments. Elemental analyses were carried out with a CI Instrument model EA1110 and MS spectra with a Jeol JMS-AX505WA.

All manipulations relating to $\operatorname{Ir}(\mathrm{III})$ complexes were carried out under nitrogen condition, although they are air stable, due to the possible oxidation and thermal decomposition of intermediate complexes during the reactions.

Chemicals: Tetra- $n$-butylammonium hexafluorophosphate $\left(\mathrm{TBAPF}_{6}\right.$, Aldrich) was used as the electrolyte in the nonaqueous experiments. 2-phenylpyridine (ppyH, Aldrich), 2phenylquinoline (pqH, Aldrich), $\mathrm{Ru}(\mathrm{bpy})_{3} \mathrm{Cl}_{2}$ (Aldrich), $\mathrm{IrCl}_{3} .3 \mathrm{H}_{2} \mathrm{O}$ (STREM), silver hexafluorophosphate $\left(\mathrm{AgPF}_{6}\right.$, Aldrich), silver trifluoroacetate $\left(\mathrm{AgO}_{2} \mathrm{CCF}_{3}\right.$, Aldrich), acetonitrile (extradry, Acros organics), dichloromethane (Samchun), ethanol (Aldrich), toluene (Samchun), tri- $n$-propylamine (98\%, Aldrich), 2,2'-bipyridine (TCI), 1,10phenanthroline (Aldrich), acetylacetone (acacH, Aldrich), and 2,2',6,6'-tetramethylhepta-3,5dione (tmdH, Aldrich) were used as received without further purification.

Synthesis of $f a c-\operatorname{Ir}(\mathbf{p p y})_{3}$ : $f a c-\operatorname{Ir}(\mathrm{ppy})_{3}$ was prepared and characterized by the method reported in the literature with minor modification. ${ }^{1}\left[\operatorname{Ir}(\mathrm{ppy})_{2}(\mu-\mathrm{Cl})\right]_{2}(1072.1 \mathrm{mg}, 1.00 \mathrm{mmol})$, $\mathrm{AgO}_{2} \mathrm{CCF}_{3}(64.2 \mathrm{mg}, 0.25 \mathrm{mmol})$, and 2-phenylpyridine $(1552.0 \mathrm{mg}, 10 \mathrm{mmol})$ were mixed and refluxed without solvent for $24 \mathrm{~h}$. Excess ligand was extracted with EtOH. The colored precipitate was filtered off, washed with ethanol and hexane and dissolved in dichloromethane. The crude product was purified by flash chromatography (silica/dichloromethane) to give the pure $f a c-\operatorname{Ir}(\mathrm{ppy})_{3}(50 \%) .{ }^{1} \mathrm{H},{ }^{13} \mathrm{C}-\mathrm{NMR}, \mathrm{MS}$, and elemental analyses results were consistent with the reported values.

Synthesis of $\left[(\mathbf{p p y})_{2} \operatorname{Ir}(\mathbf{b p y})\right]^{+} \mathbf{P F}_{6}{ }^{-}:\left[\mathrm{ppy}_{2} \operatorname{Ir}(\mathrm{bpy})\right]^{+} \mathrm{PF}_{6}^{-}$was prepared and characterized by the method reported in the literature with minor modification. ${ }^{2}\left[\operatorname{Ir}(\mathrm{ppy})_{2}(\mu-\mathrm{Cl})\right]_{2}(300 \mathrm{mg}$, $0.28 \mathrm{mmol}$ ) and 2,2'-bipyridine (100 $\mathrm{mg}, 0.64 \mathrm{mmol})$ were dissolved in dichloromethane (20 $\mathrm{ml}$ ) and the solution was refluxed for $6 \mathrm{~h}$. The solvent was removed on a rotary evaporator. The remaining yellow solids were washed with the mixed solvents of diethyl ether and hexane three times $(3 \times 20 \mathrm{ml}$ ) in order to remove excess 2,2'-bipyridine. The crude product was dissolved in dichloromethane and purified by flash chromatography (silica/dichloromethaneethanol), followed by solvent removal on a rotary evaporator. The dark orange powder was re-dissolved in dichloromethane, which was extracted with $30 \mathrm{ml}$ of $2 \mathrm{~N} \mathrm{HCl}$ (2 times). Two times of precipitation from dichloromethane into toluene gave a dark yellow solid product, $\left[\mathrm{ppy}_{2} \operatorname{Ir}(\mathrm{bpy})\right] \mathrm{Cl}\left(60 \%\right.$ yield). To the dichloromethane solution $(20 \mathrm{ml})$ of $\left[\mathrm{ppy}_{2} \operatorname{Ir}(\mathrm{bpy})\right] \mathrm{Cl}(300$ 
$\mathrm{mg}, 0.43 \mathrm{mmol}), \mathrm{AgPF}_{6}(250 \mathrm{mg}, 0.99 \mathrm{mmol})$ was added and the resulting solution was stirred for $1 \mathrm{~h}$. The precipitate was filtered off and washed with excess dichloromethane. The filtrate was purified by chromatography on a silica column using dichloromethane and then ethanol for elution. The solvent was removed on a rotary evaporator. Two times of precipitation from dichloromethane into toluene gave the orange solid product, $\left[\mathrm{ppy}_{2} \operatorname{Ir}(\mathrm{bpy})\right] \mathrm{PF}_{6}(80 \%$ yield $) .{ }^{1} \mathrm{H},{ }^{13} \mathrm{C}-\mathrm{NMR}, \mathrm{MS}$, elemental analyses results were consistent with the reported values. ${ }^{1} \mathrm{H}$ NMR $\left(300 \mathrm{MHz}\right.$, dichloromethane- $\left.d_{2}\right)$, ppm: 9.30 (d, 2H, J 8.2 Hz), 8.22 (t, 2H, J 7.95 Hz), 7.94 (m, 4H), 7.73 (m, 4H), 7.50 (d, 2H, J 5.4 Hz), 7.44 (t, 2H, $7.45 \mathrm{~Hz}), 6.99(\mathrm{~m}, 6 \mathrm{H}), 6.32$ (d, 2H, 7.5 Hz). ${ }^{13} \mathrm{C}$ NMR (75.47 MHz, dichloromethane- $d_{2}$ ), ppm: 168.24, 156.55, 150.82, 150.79, 149.05, 144.21, 140.30, 138.64, 132.14, 131.15, 128.57, 126.77, 126.41, 125.38, 123.79, 123.12, 120.33. Anal. Calcd for $\operatorname{IrC}_{32} \mathrm{H}_{24} \mathrm{~N}_{4} \mathrm{Cl} \cdot\left(\mathrm{CH}_{2} \mathrm{Cl}_{2}\right): \mathrm{C}$ 51.00, H 3.37, N 7.21. Found: C 51.45, H 3.61, N 6.68. HR-FAB-MS: calculated [M-PF $]^{+}$ 656.7894; observed [M-PF $]^{+}$657.1630

Synthesis of $\left[(\mathbf{p p y})_{2} \operatorname{Ir}(\mathbf{p h e n})\right]^{+} \mathbf{P F}_{6}{ }^{-}$: Procedures used in the preparation and purification of $\left[\mathrm{ppy}_{2} \operatorname{Ir}(\mathrm{phen})\right]^{+}$were analogous to those described for $\left[\mathrm{ppy}_{2} \operatorname{Ir}(\mathrm{bpy})\right]^{+} .{ }^{1} \mathrm{H}$ NMR $(300 \mathrm{MHz}$, DMSO-d $d_{6}$ ), ppm: 8.91 (d, 2H, J $5.6 \mathrm{~Hz}$ ), 8.39 (s, 2H), 8.26 (d, 2H, J $\left.3.7 \mathrm{~Hz}\right), 8.20$ (d, 2H, J $2.4 \mathrm{~Hz}), 8.05(\mathrm{~m}, 2 \mathrm{H}), 7.95(\mathrm{~d}, 2 \mathrm{H}, 3.4 \mathrm{~Hz}), 7.87(\mathrm{~m}, 2 \mathrm{H}), 7.46(\mathrm{~d}, 2 \mathrm{H}, 2.7 \mathrm{~Hz}), 7.01(\mathrm{~m}, 6 \mathrm{H})$, 6.29 (d, 2H, 3.8 Hz). ${ }^{13} \mathrm{C}$ NMR (75.47 MHz, DMSO- $\left.d_{6}\right)$, ppm: 166.86, 150.64, 149.83, 149.10, $146.10,144.01,138.38$, 138.71, 131.26, 131.16, 130.22, 128.36, 127.13, 125.06, 123.86, 122.40, 119.97. Anal. Calcd for $\mathrm{C}_{34} \mathrm{H}_{24} \mathrm{~F}_{6} \mathrm{IrN}_{4} \mathrm{P}: \mathrm{C} 49.54, \mathrm{H} 2.93, \mathrm{~N}$ 6.78. Found: $\mathrm{C} 49.54, \mathrm{H}$ 3.17, N 6.78. FAB-MS: calculated $\mathrm{M}^{+} 825.8$; observed $\mathrm{M}^{+} 826.0$

Synthesis of $(\mathbf{p q})_{2} \operatorname{Ir}(\mathbf{a c a c})^{\mathbf{1}(\mathbf{b})}:\left[\operatorname{Ir}(\mathrm{pq})_{2}(\mu-\mathrm{Cl})\right]_{2}$ complex $(0.078 \mathrm{mmol}), 0.2 \mathrm{mmol}$ of $2,4-$ pentanedione (acetylacetone, acacH), $0.1 \mathrm{ml}$ of $2 \mathrm{~N} \mathrm{NaOH}$ were stirred in 2-ethoxyethanol for $24 \mathrm{~h}$. The colored precipitate was filtered off, washed with ethanol and hexane and dissolved in dichloromethane. The crude product was purified by flash chromatography (silica/dichloromethane) or recrystallization to give the pure $(\mathrm{pq})_{2} \operatorname{Ir}(\mathrm{acac})(80 \%) .{ }^{1} \mathrm{H}$ NMR (500 MHz, DMSO-d $)$, ppm: 8.52 (d, 2H, J 8.8 Hz), 8.38 (m, 4H), 8.01 (m, 4H), 7.56 (m, 4H), 6.89 (t, 2H, J $14.9 \mathrm{~Hz}), 6.54$ (t, 2H, J $14.6 \mathrm{~Hz}), 6.29$ (d, 2H, $7.6 \mathrm{~Hz}), 4.70$ (s, 1H), 1.46 (s, $6 \mathrm{H})$. Anal. Found: C 59.76, H 3.86, N 3.92. Calcd: C 60.07, H 3.89, N 4.00. FAB-MS: calculated $\mathrm{M}^{+} 700.17$; observed $\mathrm{M}^{+} 700$.

Synthesis of $(\mathbf{p q})_{2} \operatorname{Ir}(\mathbf{t m d})^{\mathbf{1}(\mathbf{b})}:\left[\operatorname{Ir}(\mathrm{pq})_{2}(\mu-\mathrm{Cl})\right]_{2}$ complex $(0.078 \mathrm{mmol}), 0.2 \mathrm{mmol}$ of $2,2^{\prime}-$ 6,6'-tetramethylhepta-3,5-dione ( $\mathrm{tmdH}), 0.1 \mathrm{ml}$ of $2 \mathrm{~N} \mathrm{NaOH}$ were stirred in 2-ethoxyethanol for $24 \mathrm{~h}$. The colored precipitate was filtered off, washed with ethanol and hexane and dissolved in dichloromethane. The crude product was purified by flash chromatography (silica/dichloromethane) or recrystallization to give the pure $(\mathrm{pq})_{2} \operatorname{Ir}(\mathrm{tmd})(80 \%) .{ }^{1} \mathrm{H} \mathrm{NMR}$ (500 MHz, DMSO- $d_{6}$ ), ppm: 8.48 (d, 2H, J 8.8 Hz), 8.38 (d, 2H, J 8.9 Hz), 8.27 (d, 2H, J 8.6 Hz), 8.01 (d, 2H, J 7.2 Hz), 7.97 (d, 2H, J 7.5 Hz), 7.53 (t, 2H, J 14.7 Hz), 7.38 (t, 2H, J 15.7 Hz), 6.88 (t, 2H, J 15.1 Hz), 6.55 (t, 2H, J 14.8 Hz), 6.37 (d, 2H, J 7.6 Hz), 4.90 (s, 1H), 0.56 
(s, 18H). Anal. Found: C 62.80, H 5.10, N 3.53. Calcd: C 62.81, H 5.01, N 3.57. FAB-MS: calculated $\mathrm{M}^{+}$784.26; observed $\mathrm{M}^{+}$784.27.

Absorbance and Photoluminescence: UV-visible spectra were measured on a Scinco 2100 spectrophotometer. Photoluminescence (PL) spectra were obtained with a Jasco FP-7500 spectrofluorometer. Excitation wavelength was $400 \mathrm{~nm}$ for the Ru(II) and $\operatorname{Ir}(\mathrm{III})$ complexes, and the PL detection was performed in the range of 410 to $730 \mathrm{~nm}$. Relative photoluminescence efficiencies of Ir(III) complexes in dichloromethane solution (degassed by several freeze-and-thaw cycles) were measured by comparing the PL intensity of the trischelate $\operatorname{Ir}(\mathrm{III})$ complexes with a reference organic dye as a standard.

Electrochemistry. Cyclic voltammetry was carried out using an electrochemical analyzer (CH Instruments 660). ECL spectra were obtained using a charge-coupled device camera (Princeton Instruments, LN/CCD 1752) cooled to below $-135{ }^{\circ} \mathrm{C}$. Stepwise potentials were generated using an electrochemical laboratory (Radiometer Analytical, Voltalab 80) and used for ECL experiments (applied voltages were ranged from 0 to $\sim 1.8 \mathrm{~V}$, depending on the $\mathrm{E}^{\mathrm{O}}(\mathrm{ox})$ of complexes, where maximum ECL intensity was usually observed at about $0.5 \mathrm{~V}$ over the $\left.\mathrm{E}^{\mathrm{o}}(\mathrm{ox})\right)$. All electrochemical and ECL experiments were referenced with respect to a silver wire as the quasi-reference electrode (AgQRE). All potentials were calibrated against an aqueous SCE by the addition of ferrocene as an internal standard, where $\mathrm{E}^{\mathrm{O}}\left(\mathrm{Fc}^{+} / \mathrm{Fc}\right)=$ $0.424 \mathrm{~V}$ vs SCE. A platinum disk (1 mm diameter) working electrode was polished on a felt with $0.05 \mu \mathrm{M}$ alumina (Buehler), rinsed with water and sonicated in absolute ethanol for 5 min. Then it was dried at $70{ }^{\circ} \mathrm{C}$ in an oven for $5 \mathrm{~min}$ before each experiment. Acetonitrile solutions for ECL measurement contained $0.1 \mathrm{mM}$ metal complex, $0.01 \mathrm{M}$ TPrA, and $0.1 \mathrm{M}$ $\mathrm{TBAPF}_{6}$ as an electrolyte. Integrated ECL area (S) of metal complexes with TPrA as a coreactant was obtained by the method reported in the literature reference, and compared with that of $\mathrm{Ru}(\mathrm{bpy})_{3}{ }^{2+}$ as the standard $\left(\mathrm{S}_{0}\right)$. Reported values are the average of at least five scans with a relative standard deviation of $\sim 5 \%$.

\section{References}

1. (a) King, K. A.; Spellane, P. J.; Watts, R. J. J. Am. Chem. Soc. 1985, 107, 1431-1432;

(b) Lamansky, S.; Djurovich, P.; Murphy, D.; Abdel-Razzaq, F.; Kwong, R.; Tsyba, I.; Bortz, M.; Mui, B. R.; Bau, B.; and Thompson, M. E. Inorg. Chem. 2001, 40, 1704 -1711 .

2. (a) Garces, F. O.; King, K. A.; Watts, R. J. Inorg. Chem. 1988, 27, 3464-3471. (b)

Wilde, A. P.; King, K. A.; Watts, R. J. J. Phys. Chem., 1991, 95, 629-634. 